\title{
Background of the formation of the modern system of musical and aesthetic education primary school students in the Republic of Korea
}

\author{
Kim 0.* \\ H.S. Skovoroda Kharkiv National Pedagogical University, Kharkiv, Ukraine
}

Received: 28.03 .2019

Accepted: 15.04 .2019

\begin{abstract}
The article discusses the early stages of the development of primary education and musical and aesthetic education of primary school students in Korea from antiquity to the middle of the twentieth century. It was established that the philosophical systems of the East - Buddhism and Confucianism - had a significant influence on the content of music education and aesthetic music education in Korea. The various forms of primary schools that appeared in Korea in the last decades of the Joseon dynasty in the late XIX - early XX century are shown private, public, Christian ones. It is noted the activities of the royal power to modernize the educational system after becoming acquainted with the musical traditions of the West. The goals of the activity of patriotic schools are named. In the frames of the First, Second, Third and Fourth Educational Policies the activities of the Japanese administration during the protectorate (1910-1945) is analyzed, which, depending on external and internal factors, fluctuated between the striving for Korean assimilation and periods of liberalization and tolerance to local traditions and customs. The content of musical textbooks for primary school students was analyzed, which were used in private patriotic schools to inspire young people at school to resist the colonial administration in order to prepare future leaders of the nation. The stages of the formation of the educational system are traced taking into account the volume of weekly training hours between various disciplines and the distribution by years of the three levels of secondary school education. A gradual increase in the time and content of musical and aesthetic education, an increase in the number of textbooks and quotas for Korean content compared with Japanese has been established. The democratization of education after the restoration of statehood in the mid-twentieth century, the transformation and development of education in the Republic of Korea in accordance with the needs of the time are analyzed. The characteristic of the Curriculum is given in relation to compulsory subjects, electives and extracurricular activities. It is established that the duration of the first degree of secondary school in the Republic of Korea, in contrast to the domestic educational system, is longer and is of six years with a large amount of weekly hours of aesthetic disciplines.
\end{abstract}

Key words: Confucianism, the Joseon period, Changga, the period of the Japanese protectorate.

\section{Передісторія формування сучасної системи музично-естетичного виховання молодших школярів в Республіці Корея}

\author{
Кім О. 0. \\ Харківський національний педагогічний університет ім. Г.С. Сковороди, Харків, Україна
}

\begin{abstract}
Анотація. У статті розглядаються ранні етапи розвитку початкової освіти і музично-естетичного виховання молодших школярів в Кореї від античності до середини XX століття. Встановлено, що значного впливу на зміст музичної освіти і музично-естетичного виховання в Кореї справили філософрські системи Сходу буддизм і конфуціанство. Показано різні форми початкових шкіл, які з'явилися в Кореї в останні десятиліття династії Чосон наприкінці XIX - початку XX століття: приватних, державних, християнських. Вказано на діяльність королівської влади на модернізацію освітньої системи після знайомства із музичними традиціями Заходу. Названо цілі діяльності патріотичних шкіл. В рамках Першої, Другої, Третьої та Четвертої Освітньої політики проаналізовано діяльність японської адміністрації в період протекторату (1910-1945рр.), яка залежно від зовнішніх і внутрішніх чинників коливалась між прагненням асиміляції корейців та періодами лібералізації і
\end{abstract}

Corresponding Author: Kim Oleksandr Oleksiyovich. Tel. +38(098)037-23-56. E-mail: kim.sungdai@yahoo.com H.S. Skovoroda Kharkiv National Pedagogical University, room 318, Valentinivska st, 2 B, Kharkiv, Ukraine, 61168.

Відповідальний автор: Кім Олександр Олексійович. Тел. +38(098)037-23-56. E-mail: kim.sungdai@yahoo.com Харківський національний педагогічний університет ім. Г.С. Сковороди, к. 318, вул. Валентинівська, 318, корп. В., Харків, Україна, 61168 
толерантності до місцевих традицій і звичаїв. Проаналізовано вміст музичних підручників для молодших школярів, які використовувалися в приватних патріотичних школах задля надихання шкільної молоді на спротив колоніальній адміністрації з метою підготовки майбутніх лідерів нації. Простежено етапи формування освітньої системи з огляду на обсяг щотижневих навчальних годин між різними дисциплінами та розподіл за роками трьох рівнів загальної шкільної освіти. Встановлено поступове збільшення часу і змісту музичноестетичної освіти, зростання кількості підручників і квот на корейський контент порівняно з японським. Проаналізовано демократизацію освіти після відновлення державності в середині XX століття, перетворення і розвиток освіти в Республіці Корея відповідно до потреб часу. Дана характеристика Навчального плану щодо обов'язкових дисциплін, факультативів та позакласної діяльності. Встановлено, що тривалість першого ступеня загальноосвітньої школи в Республіці Корея на відміну від вітчизняної освітньої системи є більшою і складає шість років із більшим при цьому обсягом тижневих годин дисциплін естетичного циклу.

Ключові слова: конфуціанство, період Чосон, чангга, період японського протекторату.

\title{
Предыстория формирования современной системы музыкально- эстетического воспитания младших школьников в Республике Корея
}

\author{
Ким А. А. \\ Харьковский национальный педагогический университет им. Г.С. Сковороды, Харьков, Украина
}

\begin{abstract}
Аннотация. В статье рассматриваются ранние этапы развития начального образования и музыкальноэстетического воспитания младших школьников в Корее от античности до середины XX века. Установлено, что значительное влияние на содержание музыкального образования и музыкально-эстетического воспитания в Корее оказали философские системы Востока - буддизм и конфуцианство. Показаны различные формы начальных школ, которые появились в Корее в последние десятилетия династии Чосон в конце XIX - начале XX века: частныX, государственных, христианских. Указано на деятельность королевской власти на модернизацию образовательной системы после знакомства с музыкальными традициями Запада. Названы цели деятельности патриотических школ. В рамках Первой, Второй, Третьей и Четвертой Образовательной политики проанализирована деятельность японской администрации в период протектората (1910-1945 гг.), которая в зависимости от внешних и внутренних факторов колебалась между стремлением ассимиляции корейцев и периодами либерализации и толерантности к местным традициям и обычаям. Проанализировано содержание музыкальных учебников для младших школьников, которые использовались в частных патриотических школах для вдохновения школьной молодежи на сопротивление колониальной администрации с целью подготовки будущих лидеров нации. Прослежены этапы формирования образовательной системы с учетом объема еженедельных учебных часов между различными дисциплинами и распределения по годам трех уровней общего школьного образования. Установлено постепенное увеличение времени и содержания музыкально-эстетического образования, рост количества учебников и квот на корейский контент по сравнению с японским. Проанализированы демократизация образования после восстановления государственности в середине XX века, преобразования и развитие образования в Республике Корея в соответствии с потребностями времени. Дана характеристика Учебного плана в отношении обязательных дисциплин, факультативов и внеклассной деятельности. Установлено, что продолжительность первой степени общеобразовательной школы в Республике Корея в отличие от отечественной образовательной системы является большей и составляет шесть лет с большим при этом объемом недельных часов дисциплин эстетического цикла.
\end{abstract}

Ключевые слова: конфруцианство, период Чосон, чангга, период японского протектората.

\section{Bcmyn}

На шляху реалізації прагнення України до світової інтеграції $€$ важливим збереження національної ідентичності, ціннісного ядра, яке визначає цивілізаційну самобутність. У галузі освіти найбільш спрямованим на виконання цього завдання є її естетична, у тому числі - музично-естетична, компонента в початкових класах загальноосвітньої школи.

Корисним при цьому є досвід націй, які знайшли вже віришення подібних проблем в культурі і освіті. Відновлення державності України наприкінці минулого століття характеризується викликами, багато у чому подібними тим, які постали перед Республікою Корея у 1948 р. При цьому ступінь наукової розробки проблеми музично-естетичного виховання учнів початкової школи в Республіці Корея в Україні не є достатнім, хоча серед етносів розвинутих країн Далекого Сходу єдине Корея вже півстоліття представлена в Україні чисельною діаспорою. 
Meта та завдання статті полягають у дослідженні передісторії формування сучасної системи музично-естетичного виховання молодших школярів у загально-освітніх школах Південної Кореї.

\section{II Матеріал і методи дослідження}

До 1876 року корейське суспільство було класовим фреодалізмом і перебувало під впливом буддизму та конфуціанства. Естетична освіта бере початок ще з часів династії Сілла близько 57 р. до н.е. - 917 р. н.е. Привілейовані чоловіки вищого класу відвідували школи і різні предмети, такі як мистецтво, поезія, музика, танці, архітектура, розпис храмів, пагод і буддійських образів, які вивчали разом з каліграфрією та філософією. Уряд навіть спонсорував школу під назвою 도화 수 (до-хва су, урядовий інститут мистецтв і живопису), який мав навчати лише профеесіоналів [5].

В останні роки Чосон музичне виховання в Кореї уперше зазнало впливу західної музики - 3 1906 р. вона вже офіційно вивчалася в школі. У зв'язку з цим, на початок XX столітття відкриваються як приватні, так і державні освітні заклади, в яких значна роль відводиться навчанню музичному мистецтву. Корейська музична культура в цей час перебуває під впливом західної та японської. Тому, поряд із засвоєнням національних традицій, певну увагу отримує опанування особливостями західних музичних дисциплін [3].

Багато початкових навчальних закладів було засновано християнськими проповідниками, перші 3 яких з'явилися в Кореї у 1885 р. У їх число увійшли такі школи, як 배재학당 (Печжехактанг), 이화학당 (Іхвахактанг, 언더우드학당 (Андервудхактанг), організована в 1886 році і пізніше перейменований в 경신학당 (Кьонгсінхактанг), жіноча школа 정신 (Чонгсін), заснована в 1887 році, жіноча школа 영화 (Йонгхва) (1890) і 숭실 학교 (Сунгсільхаккьо) (1897). Вже в 1891 р. в академічний план школи Іхвахактан були включені такі предмети, як вокал і виконавство [2].

У той же час уряд Чосон намагався створити свою власну модернізовану систему корейської освіти. Школи в цей період можуть бути класифіковані на три типи залежно від способу їх організації: 서당 (со дане - приватні неформальні школи або конфуціанські академії), які були традиційною шкільною системою династії Чосон; 보통 학교 (ботхонг хаккьо - початкові школи, японські колоніальні державні школи); Приватні школи (патріотичні і християнські) [6].

Протягом першого десятиліття 1900-х років кількість патріотичних шкіл досягла свого піку. У липні 1910 року до анексії існували 2250 затверджені приватні школи. Якщо врахувати офріційно незатверджені приватні школи, наприклад вечірні шкіл та сільські школи, вважається, що загальна кількість складала приблизно 6000 [10].

Основною метою патріотичних шкіл було досягнення сильної нації: етично: розбиваючи класову систему (сувору ієрархію класів династії Чосон) і створення нового суспільства; філософрськи: прийнявши нове і сучасне мислення, освіту і культуру від західних країн; педагогічно: шляхом введення нової та сучасної системи освіти.

Зокрема, патріотичні школи мали свої власні видані підручники, спрямовані на розвиток патріотизму і учнів.

Після 1910 р. з цих трьох систем шкільного навчання, колоніальна система початкової школи ботхонг хаккьо була єдиною, офріційно визнаною колоніальним урядом, і жорстко контролювалася через канцелярію японського генерал-губернатора. Існувало два різних типи приватних шкіл: патріотичні і християнські школи. Був цілий ряд інших неофіційних приватних шкіл, таких, як вечірні та сільські школи. Проте, патріотичні школи становлять найбільший інтерес, оскільки вони явно підтримували незалежну Корею [6].

У липні 1895 року Корейський відділ освіти проголосив Положення про початкову школу 소학교렝 (Сохагкьоренг) - перший приклад сучасного регулювання освіти. Оскільки музика не згадується в цій постанові, вважається, що офіційно в той час в Кореї не було викладання музики в школі. 
Майже десять років по тому у 1906 р. під впливом Японії 창가 (чангеа, букв. розспіви) з'явилася в Положенні 보통 학교 (ботхонг хаккьо - початкові школи, японські колоніальні державні школи) [12]. Цілі Чангга та зміст підручників з корейської музики були ідентичні тим, які використовувалися в Японії. Фактично, всі матеріали, пов'язані з музикою, включаючи правила, навчальні програми та підручники, були буквально скопійовані з японських [6]. Модернізація швидко поширилася і зайняла своє місце в корейському суспільстві. Вона принесла загальну освіту для всіх учнів і навіть естетична освіта посіла місце в стандартній предметній навчальній програмі. Ця практика була недовгою через 울사 보호 조약 (ульса бохо чояе, договір про захист) 1905 року, який був підписаний між Японією і Кореєю. В результаті цього договору вся корейська система освіти контролювалася японською адміністрацією. Естетична освіта була вилучена з навчальної програми, оскільки японці вважали, що естетична освіта, як і мистецтво, є одним з небезпечних інструментів для сприяння звільненню корейського народу. Вони вважали, що естетичне виховання сприяє формуванню «індивідуальної автономії», що було заборонено, як і мовлення корейською мовою. Основною освітньою спрямованістю був розвиток робочої сили з навичками ручної праці [5].

«Ера військової політики» (1910-1918) почала впливати на систему корейської освіти, яку швидко і повністю було модифіковано шляхом прийняття колоніальним урядом багатьох шкільних правил. Перший генерал-губернатор Тераучі Масатака зробив довгу промову в липні 1911 р. про те, яку систему колоніальної освіти треба створити в Кореї: «Освіта в Чосон - це все, що має перетворити корейців у відданих японських підданих. Тому Ботхонг хаккьо повинна викладатися, і практична освіта $\epsilon$ пріоритетним завданням» [17]. Через місяць після цього виступу було проголошено Першу Освітню Політику Чосон (1911-1922рр.), яка включла в себе в загальній складності тридцять статей, 3 декількома важливими функціями. По-перше, нещодавно створена система корейської освіти змінювалася в японську. По-друге, метою освіти називалося сприяння корейцям стати хорошими і вірними підданими Японії. По-третє, японську мову було визнано національною мовою Кореї. Почетверте, Японія скоротила тривалість початкової школи з шести років за традиційною корейською системою до чотирьох. По-п'яте, цілі політики колоніального освіти завжди були безпосередньо пов'язані з цілями японської колоніальної політики. Японія хотіла, аби корейські діти навчалися таким чином, щоб безпосередньо підтримувати плани Японії щодо економічної експлуатації. Крім того, перешкоджання здобуттю старшої освіти зменшувало ймовірність появи майбутніх інтелектуалів, які б могли кинути виклик японській окупації [6].

Всього два роки після анексії Кореї Японією в 1910 р. в офіційному бюлетені генерал-губернатора було оголошено Положення про Приватну Школу. 3 цього часу, відкриття приватних шкіл передбачало задоволення певного набору строго регламентованих критеріїв. Крім того, були дозволені тільки підручники, затверджені генерал-губернатором, тим самим позбавляючи приватні школи більшої частини їх навчального матеріалу [14].

Патріотичні школи використовували музику по-іншому, аби розвивати патріотичні почуття в корейських дітей. у 1996 році Міністерством Патріотів і у Справах Ветеранів Кореї було знайдено оригінальний музичний підручник, який використовувався в приватних школах. Цей підручник називався 최신 창가집 부악 전 (Книга Нової Музики Чангга) і був використаний в Маньчжурській середньій школі в Китаї, одній з декількох приватних шкіл, побудованих корейцями, які жили у вигнанні, і, ймовірно, був опублікований в 1914 р. Він містив 152 Чангга. Тексти пісень, які використовувалися в приватних школах по всій Кореї, складалися з тем надії на незалежність і прагнення Кореї до патріотизму [6].

Одна з найвідоміших патріотичних пісень була написана Ан Чанг-Хо (1878-1938), відомим корейським активістом за незалежність, який емігрував до США в квітні 1910 р. «Пісню для всієї країни» (거국가 (去國歌), Когукка) було опубліковано в 대한 매일 신보 (Щоденні новини Кореї) 12 травня 1910 р. Вона швидко поширилася в Кореї і серед корейців за кордоном. Вважається, що текст національного гімну Кореї 애국 가 (Егукка) також був написаний Ан Чанг-Хо. 
Спочатку ці пісні були заспівані до мелодії шотландської народної пісні Auld Lang Syne (Добрий старий час). Корейський національний гімн Егукка був однією з найзначніших пісень, яких навчали, і його співали на демонстраціях під час найбільшого повстання, організованого корейцями 1 березня 1919 р. проти японської окупації, на мелодію Auld Lang Syne, яку 15 серпня 1948 р. на церемонії святкування заснування Республіки Кореї було замінено складеною Ан Іг-те в 1935 році - ця версія національного гімну використовується донині [6].

В свою чергу християнські школи також відігравали таку ж роль, що й патріотичні школи. Вплив християнства на сучасну корейську музики $є$ значним. Вчителі у християнських школах були в основному місіонерами, корейські музиканти, західники, і корейські учні, які навчалися за кордоном. У позакласних заходах діти співали найпопулярніші пісні, такі як корейський національний гімн (애국가) i 소년 행진가 (сонньон хенгчінга - похідна пісня хлопчиків), складений Ан Чанг-Хо. Ці пісні співали на вулиці, як пісні протесту [13].

Через сильний опір корейців колонізації в 1919 р. колоніальний уряд змінив свою колоніальну політику в галузі освіти на основі нової «культурної політики». Ця політика була більш ліберальною і дозволяла більше свободи в Кореї. Друга Освітня Політика Чосон освіти була оголошена в 1922 р. 3 деякими помітними змінами порівняно із Першою. Тривалість навчання корейців було розширено, аби співпадала з японськими школами в Кореї: початкова школа - від чотирьох до шести років, старша школа (хлопчики) - від чотирьох до п'яти років, а також старша школа (дівчатка) - від трьох до чотирьох або п'яти років. Корейська мова, яку було скасовано в ході Першої Освітньої Політики, в цей час стала обов'язковим предметом, хоча японська залишалася як національна мова [6]. Таблиця 1 містить перелік обов'язкових предметів і кількість годин на тиждень, присвяченій кожній (за рік шестирічної початкової школи). Згідно з цією таблицею, японська історія і географія були введені в перший раз у 5-му і 6-му класі. У той час як корейська мова з'явилася в цій навчальній програмі, години японської мови переважають від 3 до 4 разів.

Табл. 1. Щотижневі години для початкової школи (х = хлопчики, д = дівчинки)

\begin{tabular}{|l|c|c|c|c|c|c|}
\hline \multicolumn{1}{|c|}{ ПРЕДМЕТИ } & Клас 1 & Клас 2 & Клас 3 & Клас 4 & Клас 5 & Клас 6 \\
\hline Етика & 1 & 1 & 1 & 1 & 1 & 1 \\
\hline Національна мова (японська) & 10 & 12 & 12 & 12 & 9 & 9 \\
\hline 조선ㅇ (корейська мова) & 4 & 4 & 3 & 3 & 3 & 3 \\
\hline Математика & 5 & 5 & 6 & 6 & 4 & 4 \\
\hline Історія (японська історія) & - & - & - & - & 2 & 2 \\
\hline Географрія & - & - & - & - & 2 & 2 \\
\hline Точні науки & - & - & - & 2 & 2 & 2 \\
\hline Мистецтва & - & - & 1 & 1 & $\begin{array}{c}\text { х: } 2 \\
\text { д: } 1\end{array}$ & $\begin{array}{c}\text { х: } 2 \\
\text { д: } 1\end{array}$ \\
\hline Чангга (музика) & - & - & 1 & 1 & 1 & 1 \\
\hline Гімнастика & 3 & 3 & 3 & $\begin{array}{c}\text { х: 3 }: 2 \\
\text { д: 3 }\end{array}$ & $\begin{array}{c}\text { д: } 3 \\
\text { д: } 2\end{array}$ \\
\hline Шиття (д) & & & & 2 & 3 & 3 \\
\hline Загалом & 23 & 25 & 27 & $\begin{array}{c}\text { х: } 30 \\
\text { д: } 29\end{array}$ & $\begin{array}{c}\text { х: } 31 \\
\text { д: } 29\end{array}$ & $\begin{array}{c}\text { х: } 31 \\
\text { д: } 29\end{array}$ \\
\hline
\end{tabular}

В особливих випадках, деяким японським дітям, які проживали в Кореї, булј дозволено відвідувати школу для корейських дітей, а іноді і корейські діти ходили до школи, призначеної для японських дітей. Кількість офріційних початкових шкіл різко зросла в період Другої Освітньої Політики. Офіційно відкриття початкової школи залежало від пожертвувань і колоніальних державних субсидій. Деякі корейці прагнули підтримати «нову систему освіти», що свідчило про їхню зацікавленість в освіті і 
готовності пожертвувати на відкриття нових шкіл. Ще однією причиною збільшення числа початкових шкіл стало введення правил, що регулюють колоніальним урядом приватні школи, що було спрямоване на скорочення кількості приватних шкіл. Оскільки допуск до вищої школи був обмежений дітьми з сімей вищого класу, які відвідували офіційні початкові школи, корейці вищого класу все частіше віддавали перевагу цим офіційним початковим школам над приватними. В окупованій країні відвідування державної школи сприймалося як краща перевірка на майбутнє, ніж відвідування школи, пов'язаної 3 попереднім, скасованим урядом [15]. В 1919 р. значні зміни були внесені в музичну освіту під новим політичним мотивом «культурної політики». Якщо тільки один підручник з музики було видано в 1920-х pp., ще вісім вийшли в 1930-і рр. В таблиці 2 перераховані підручники і відомості про їх публікації [11].

Табл. 2. Підручники з музики, видані в ході Другої Освітньої Політики (1922-1938)

\begin{tabular}{|c|l|}
\hline Рік & \multicolumn{1}{|c|}{ Назва } \\
\hline 1926 & Додатковий Чангга для початкової школи \\
\hline 1932 & Третій клас початкової школи \\
\hline 1934 & Шостий клас початкової школи \\
\hline 1935 & Перший клас початкової школи \\
\hline 1935 & Другий клас початкової школи \\
\hline 1935 & Третій клас початкової школи \\
\hline 1935 & Четвертий клас початкової школи \\
\hline 1935 & П'ятий клас початкової школи \\
\hline 1935 & Шостий клас початкової школи \\
\hline
\end{tabular}

Поширеність корейських текстів збільшилася в порівнянні з підручниками в 3 попереднього періоду. Додатковий Чангга містив 21 пісню корейською мовою і 39 - японською. У збірнику 47 пісень переважно про природу, 4 - про користь навчання. Тексти інших пісень пов'язані з корейською історією і містами, легендарними корейськими горами і історією великих корейців; жодна взагалі не пов'язана 3 японським мілітаризмом. Деякі тексти пісень є результатом публічних конкурсів, організованих генералгубернатором, виграшні тексти - 16 японською мовою, складені японцями, 13 корейською мовою [6]. Деякі пісні з цього підручника і досі співають сьогодні, зокрема, в церковних службах.

На відміну від офіційних початкових шкіл, які використовували дидактичний матеріал, наданий колоніального урядом, приватні школи використовували свої власні самостійно видані музичні підручники. Тільки у період Другої Освітньої Політики Чосон (1922-1938), було опубліковано 26 приватних книг Чангга. Ця велика кількість опублікованих книг відображає більш толерантне ставлення колоніального уряду під час «культурної політики» 1920-х років, спрямоване на умиротворення корейського опору. Книги Чангга для приватних шкіл були написані корейською мовою корейськими композиторами і в значній мірі уникли японських музичних елементів. Нажаль, в цих підручниках 3 музики для приватних шкіл традиційні корейські музичні компоненти не використовувалися, в 1930-х рр. переважали західні стандарти [11].

У навчальному плані на 1930 рік предмети загальної музичної освіти набувають спеціалізовану спрямованість, а роль більшості дисциплін практичної майстерності ще більш посилюється. В області спеціальності, крім вже наявної фортепіанної, включені скрипкова і вокальна спеціалізації. У зв'язку з цим засновувалися нові предмети (вокал, італійська мова, східна пісня), в культурно-просвітницькій сфрері (англійська мова, розповіді про музику, читання, твір, розмова, граматика, література), і в ссрері педагогіки (психологія, методика викладання вокалу, хорознавство, методика викладання церковного органу, музикознавство в початковій школі, педагогіка). Вводилися нові курси лекцій, завдяки чому відбулося розгалуження системи музичної освіти. Крім цього, значна частина навчальних предметів 3 музичної педагогіки вперше стала домінувати в списку предметів для викладання [1].

3 початком Другої китайсько-японської війни в 1937 році, Японія стала все більш мілітаристською щодо сусідніх країн Азії. Для того, щоб перетворити Корею в стратегічно важливу військову базу і надійний плацдарм для військових дій в Китаї, колоніальний уряд повністю змінив свою колоніальну політику. В рамках цього в 1938 р. була оголошена Третя Освітня Політика, спрямована на японську 
асиміляцію корейських дітей. Одним з найбільш важливих проявів Третьої Освітньої Політики було те, що корейська мова повністю зникла з навчального плану і її використання було повністю заборонено в школі відповідно до щотижневого графріку. При цьому було значне збільшення кількості годин на тиждень, присвячених музиці, з максимальним збільшенням від трьох до шести годин. Це включало військові навчання, деякі з яких були взаємозамінні з бойовими мистецтвами. Можна припустити, що значну частку часу, присвяченого музиці та мілітаристським видам спорту, було пов'язане з прагненням колоніального уряду підготувати дітей до війни [6].

у 1938 р. був оголошений Національний Закон про повну мобілізацію, аби збільшити акцент на мобілізацію громадян в Кореї на війну в 1940-х роках. В 1941р. було проголошено Положення про Початкову Школу, і наступна пряма вказівка імператора знову змінила назву початковій школі, на цей раз від 소학교 (сохаккьо - молодша школа) в 국민 학교 (гукмін хаккьо - букв. школа для відданих суб'єктів Японської Імперії, тобто Японії і окупованих територій Кореї і Тайваню). Ця зміна в термінології була важливою, оскільки вона ще більше підкреслювала вагу, якої надавали школам як інструменту підготовки громадян до війни; іншими словами, початкові школи - це не просто школи, а також пропагандистські інструменти для перетворення учнів на відданих суб'єктів імперії, як в Японії, так і на окупованих територіях. Молодіжні організації були ще одним інструментом для створення конформістської молоді. Для всього цього музика часто використовувалася як інструмент пропаганди. Кількість годин Чангга на тиждень під час Третьої Освітньої Політики надано в таблиці 3. Як і в попередні роки, Чангга залишалия взаємозамінним із гімнастикою [6].

Табл. 3. Кількість годин, що відводилися на тиждень для Чангга/Гімнастика в період Третьої Освітньої Політики

\begin{tabular}{|l|c|c|c|c|c|c|}
\hline & Клас 1 & Клас 2 & Клас 3 & Клас 4 & Клас 5 & Клас 6 \\
\hline Changga / Гімнастика & 4 & 4 & 1 & 1 & 2 & 2 \\
\hline
\end{tabular}

У цей період термін для позначення початкової школи було змінено на Сохаккьо, і всі підручники, в тому числі книга Чангга, повинні були бути офіційно затверджені генерал-губернатором або Департаменту освіти. Хоча багато навчальних посібників з музики, які використовувалися в приватних школах, було опубліковано неофріційно в 1920-і і 1930-і рр. у зв'язку з більш толерантною культурною політикою, між 1938 і 1940 рр. багато з них були заборонені і опинилися в списку заборонених книг, опублікованому у 1941 р. Департаментом освіти при генерал-губернаторі [6].

Як приклад, перший підручник з музики в цьому списку, «Японська пісня» (Mikueui norae), опублікований в 1939 році, містив 11 пісень, в тому числі японський гімн, клятву вірності імператору, святкування Нового року з обіцянкою коритися імператору, святкування дня заснування Японської Імперії, похвали імператора та інші ритуальні або обрядові пісні.

Пісня 애국 헹진곡 («Патріотичний марш») $€$ прикладом взаємозв'язку між збільшенням мілітаризму у політиці і шкільними піснями. Ця пісня посіла перше місце на конкурсі текстів пісень, організованому в 1937 р. Кабінетом міністрів Японії. В результаті ця пісня була випущена шістьма великими звукозаписними компаніями і було продано більше одного мільйона примірників. «Патріотичний марш» співали не тільки солдати, а й на всіх офіційних зустрічах і в шкільних церемоніях як патріотичну пісню, навіть незважаючи на те, що вона насправді не фігурувала в музичних підручниках школи [6].

Відповідно до Четвертої Освітньої Політики Чосон (1943-1945), початкова школа була перейменована Гукмін хаккьо, і Чангга став терміном, який використовувався для позначення музичного предмету в цілому. Ще шість музичних підручників були опубліковані, які містили в цілому 161 пісень, всі - японською мовою. 3 них 74 містили мілітаризм, вихваляння Японії і японського імператору. Це представляло найбільший відсоток японських тематичних текстів за усі періоди. Тематичний зміст і використання виключно японської мови свідчить про зв'язок освіти з японським імперіалізмом і мілітаризмом у часи, коли Японія була в стані війни, і використання музики в школі як інструменту мілітаристської пропаганди [6]. 
У той час, національні лідери, які чинили опір японському вторгненню, поєдналися у «русі за порятунок нації через освіту». їх основна увага була зосереджена на підготовці майбутніх лідерів, які б домоглися національної незалежності [7].

Як свідчать історичні матеріали того періоду, метою окупаційної влади було прищепити молоді уяву про неповноцінність корейської культури. Наслідки цього продовжували діяти і після визволення. Історичні факти стверджують, що одразу після відродження державності - проголошення Республіки Корея 15 серпня 1948 р. - питання освіти із особливим наголосом на естетичне виховання стало одним із пріоритетних напрямків законотворчої діяльності. Корейський уряд наголосив на важливості нематеріальних цінностей (Jungyo Munhyeong Munhwajae). Протягом другої половини XX століття музична програма змінювалася із збільшенням частки корейської традиційної музики в порівнянні із західною музикою в школі, яка певною мірою перетворила корейське музичне виховання в багатокультурну систему, з метою повернення почуття ідентичності в корейському суспільстві [6].

\section{III Результати}

Кожного разу, коли політична ситуація в Японії змінювалася, політична орієнтація музичної освіти в колоніальній Кореї йшла за тим, як, наприклад, зменшення корейських текстів в підручниках з музики після того, як уряд Японії став мілітаристським. Це ясно показує тісний взаємозв'язок між політикою і музичною освітою. Тим не менше, період протекторату характеризувався формуванням близької до сучасної системи рівнів загальної освіти. Приватні школи, зокрема, патріотичні, зіграли значну роль в навчанні; тексти пісень щодо незалежної Кореї заохочували патріотизм учнів. Одним із проявів діяльності приватних патріотичних шкіл було створення національного гімну Егукка. Це лірика націоналістичного характеру, подібно до гімнів інших країн. Корейський гімн використовує безліч метафоричних фраз, такі як «Поки не висохне Східно-Китайське море і не зітреться гора Пекту-сан (гори духовного значення для корейців)», натякаючи на вічність Кореї. Він також включає в себе безліч барвистих виразів, що відносяться до природи. Перш за все, це надихає патріотизм і відданість Кореї.

$$
\begin{aligned}
& \text { 동해물과 백두산이 마르고 닳도록 } \\
& \text { 하느님이 보우하사 우리 나라만세 }
\end{aligned}
$$

\section{무궁화 천리 화려강산}

대한사람 대한으로 길이 보전하세

$$
\text { 남산 위에 저소나무 철갑을 두른 듯 }
$$$$
\text { 바람 서리 불변함은 우리 기상일세 }
$$

$$
\text { 가을 하늘 공활한데 높고 구름 없이 }
$$$$
\text { 밝은 달은 우리 가슴 일편단심일세 }
$$

$$
\begin{aligned}
& \text { 이기상과 이맘으로 충성을 다하여 } \\
& \text { 괴로우나 즐거우나 나라 사랑하세 }
\end{aligned}
$$

Поки не висохне Східно-Китайське море

I не зітреться гора Пекту-сан,

Хай славиться вічно Наша країна,

Яку благословляє Господь!

Суданські мальви

На тисячі миль по всюди -

Гей, корейці, захистимо навіки

Велику Корею!

Як сосна вікова на Південній горі

опирається вітру і снігу

В обладунках залізних,

Так і дух наш буде незламним!

Широке осіннє небо

Безхмаре і чисте,

Ясний місяць в наших серцях,

непохитно вірних!

3 таким духом і серцями

Будемо вірно,

І в скорботі, і в радості

Любити нашу країну!

У повній відповідності до буддистської і конфуціянської традиції, якій слідує корейська музична естетика, тексти і музика обох пісень сповнені ліризму і не містять жодного натяку на агресію, жодної згадки про ворогів, як це притаманне гімнам багатьох країн і народів, створених у часи боротьби за незалежність або проти тиранії. 


\section{IV Обговорення}

Після звільнення від 35 років японського колоніального правління в 1945 році була створена основа для демократичної освіти. Освіта в Кореї зазнала численних перетворень і розвитку на основі мінливих завдань відповідно до потреб часу, Уряд встановив напрямок демократичної освіти, розширення базової освіти, зміцнення демократії, кількісне зростання в сфері освіти, реформи системи освіти і якісне зростання освіти [7].

Корея має наскрізну 6-3-3-4 (роки) систему, яка підтримує єдину лінію рівнів школи для того, щоб гарантувати, що кожен громадянин може отримати первинну, вторинну і третинну освіту без дискримінації і відповідно до здібностей кожного учня.

На часі Навчальний план Республіки Корея включає обов'язкові дисципліни, фракультативні види діяльності та позакласну діяльність (табл. 4) [8]. До обов'язкових належать корейська мова, етичне виховання, соціальні науки, математика, природничі науки, практичні науки, фрізичне виховання, музика і мистецтва. У першому і другому класі фрізичне виховання, музика і мистецтва поєднані у єдину дисципліну «радісне життя» [9]. При цьому обсяг годин дисциплін етично-естетичного циклу складає $32.4 \%$ у першому класі, $36.4 \%$ у другому класі, $12 \%$ у третьому класі і $12.5 \%$ у четвертому класі [16]. Наслідком значної уваги до дисциплін музичного циклу виявилося те, що близько половини учнів четвертого класу грають на фрортепіано і вважають його найпопулярнішим інструментом [4].

Табл. 4. Навчальний план Республіки Корея [8]

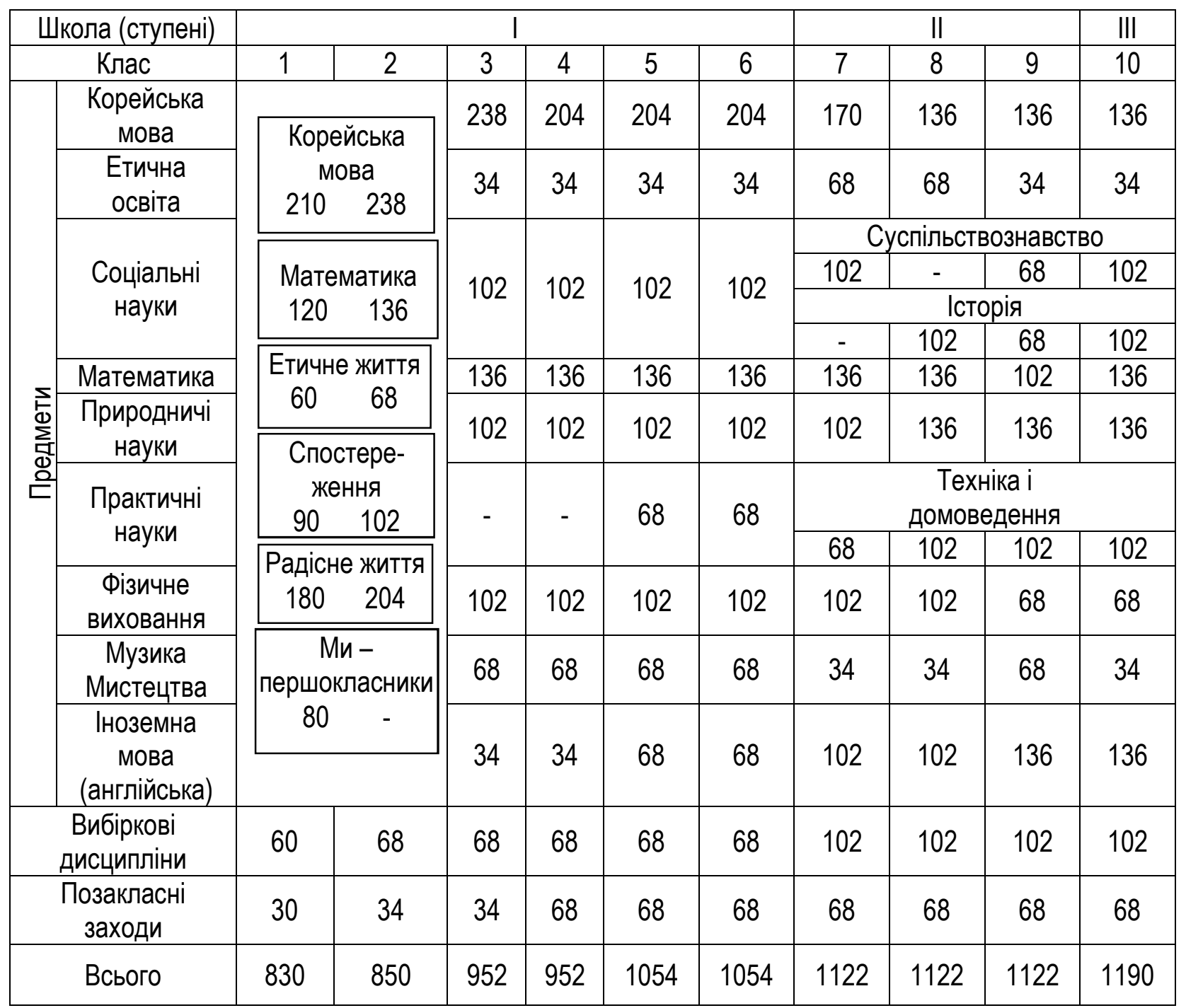

Чинний Закон Про Освіту був замінений Законом Про Базову Освіту, Законом Про Початкову Та Середню Освіту і Законом Про Вищу Освіту в 1998 р. Закон Про Початкову Та Середню Освіту охоплює 
питання, які стосуються дошкільної, початкової і середньої освіти, в той час як Закон Про Вищу Освіту відноситься до питань, пов'язаних з вищою освітою. Стаття 9 Закону Про Базову Освіту передбачає, що «Повинні бути створені школи для забезпечення дошкільної, початкової, середньої та вищої освіти» Відповідно до статті 2 Закону Про Початкову Та Середню Освіту, наступні типи шкіл повинні бути встановлені для дошкільної, початкової і середньої освіти: Дитячі садки; Початкові школи, Громадянські школи; Середні школи, Громадянські Середні школи; Середні школи, Професійні Середні школи; Спеціальні школи; Мішані школи.

Міністерство освіти контролює національну шкільну програму, як позначено в статті 23 Закону Про Початкову I Середню Школу, для того, щоб забезпечити рівні можливості отримання освіти для всіх і підтримки якості освіти. Національний навчальний план і регіональні рекомендації надають індивідуальним школам гнучкість відповідно до особливостей та завдань кожної школи [7].

\section{V Висновки}

Естетична освіта в Кореї бере початок з античних часів і, як окремий предмет, виникла в XV ст.

Музично-естетичне виховання регламентувалися Законами про освіту Чосон і здійснювлося у різних типах шкіл: приватних неформальних, державних початкових, патріотичних, а також християнських, які з'явилися наприкінці XIX - початку XX ст. після появи в Кореї місіонерів-християн.

Патріотичні школи мали власні музичні підручники і ставили за мету досягнення сильної нації.

Перший період після анексії Кореї Японією знаменувався спробами колоніальної влади асимілювати населення півострова. Однак, паралельно із державними продовжували свою діяльність приватні патріотичні школи, у яких використовувалися видані за межами Кореї музичні підручники 3 текстами пісень, з тем надії на незалежність і прагнення Кореї до патріотизму, один з яких на часі $€$ текстом Державного гімну Республіки. У подальші часи колоніальна влада відновила шестирічний термін початкової школи з виокремленням корейської мови як самостійного предмету та збільшенням частки корейських пісень в рамках предмету музики.

Можна констатувати, що за формою сучасна структура музично-естетичного виховання склалася в колоніальний період 1910-1945 pр.

\section{Бібліографічні посилання}

[1] Ан Су Ми. Диалог культур в истории Кореи: дис. ... канд. пед. наук: 24.00.01 / М., 2005. 177 с.

[2] Ан СуМи. Становление системы музыкального образования в Южной Кореe. URL: http://www.tsutmb.ru/nayk/nauchnyie_meropriyatiya/int_konf/mezhdunarodnyie/aktualnyie_problemyi_ soczialno_kulturnoj_deyatelnosti/konkurs_na_luchshee_osveshhenie_aktualnyix_voprosov_

soczialnoj_tematiki_v_rossii/stanovlenie_sistemyi_muzyikalnogo_obrazovaniya_v_yuzhnoj_koree (дата звернення: 25.04.2019)

[3] Тайшина У.С. Музыкальное образование в Корее. Якутск: Высшая школа, институт им. В.А. Босикова. Музыка для всех № 4, июль 2015. С. 20-23.

[4] Auh Myung-sook, R. Walker. Korea / Musical Development and Learning: The International Perspective // A.C. North, D.J. Hargreaves (eds). Chapt. 8. «Continuum». London-New York, 2001. P. 102-120.

[5] Kean K.H. A Historical and Social Perspective of Korean Art Education / Georgia State University (USA), 2006. 113 p. URL: https://scholarworks.gsu.edu/cgi/viewcontent.cgi?article=1005\&context=art_design_theses (дата звернення: 25.04.2019)

[6] Kim Jeong-Ha. Korean Primary School Music Education during Japanese Colonial Rule (1910-1945). 2013. 268 p. URL: https://research-repository.griffith.edu.au/handle/10072/367474 (дата звернення: 25.04.2019)

[7] Overview: The Development of Education. URL: http://english.moe.go.kr/sub/info.do?m= 020101\&s=english (дата звернення: 25.04.2019)

[8] «The School Curriculum of the Republic of Korea» Proclamation \#2008-3 of the Ministry of Education and Human Resources Development of the Republic of Korea. 2008. 53 p. URL: http://ictmsn.org/curriculum/the school curriculcum of the republic of Korea-2009.pdf (дата звернення: 25.04.2019)

[9] «The School Curriculum of the Republic of Korea» Proclamation \#2008-160 of the Ministry of Education, Science and Technology of the Republic of Korea. 2008. 133 p. URL: http://gangwonepik.weebly.com/ uploads/1/3/8/5/13851570/national_school_curriculum-english2008.pdf (дата звернення: 15.06.2018)

[10] 김형목, 오성철. 초등교육의 역사적 탐색: 일제강점기 사설초등 교육기관의 역할 - 한말 1920년대를 중심으로 / 토론. - 발행기관: 한국 초등 교육학회 간행물: 한국 초등 교육학회 학술발표논문집 2003권 0호 발행 연도: 2003 페이지: pp. 145-170 (26 pages) (Кім Хьонг-мун, О Сонг-чоль. Історичне дослідження початкової 
освіти: Роль приватних початкових навчальних закладів в періоді окупації Японії - орієнтація на корейську мову до 1920-х рр. Обговорення // Освітня конфреренція «Початкова освіта в Кореї». Видавництво початкової освіти, 2003. C. 145-170)

[11] 김혜정. 일제하 음악교육정책 연구: 학위논문사항 학위논문 (석사) - 목원 대학교 대학원: 음악학과. - 大田 : 牧園大學校. 1998. 199쪽 (Кім Хє-чонг. Дослідження політики музичної освіти в часи японської окупації: Дипломна робота магістра за спец. «Основи музикознавства». Університет Моквон, кафедра музики, 1998. 199 с.)

[12] 박제홍. 일제 강김⽇日歌에 나타난修身교육 - 조선총독부편찬 「新編唱歌集」「普通學校唱歌書」를 중심으로. 일본 교육, 2010 53권. pp. 211-227 (Пак Че-хонг. Пісенна освіта Чангга під час японської колоніальної влади - Генерал-губернаторські збірки Кореї пісень, орієнтовані на початкову школу «Нова збірка пісень», «Збірка пісень для молодшої школи» / Японська освіта, 2010. Т. 53. С. 211-227)

[13] 박혜정. 서양음악의 전래와 수용 - 1880 대를 기점으로 한 개화기 중심으로. - 국악과교육 23권0호, 2005년 12월. 페이지: 231-266 (36 pages) (Пак Хє-чонг. Поява і сприйняття західної музики - Орієнтація на період цвітіння 3 1880-х рр. / Корейська традиційна музична освіта. Т. 23, 2005.12. С. 231-266)

[14] 손인수. 한국근대교육사 (1885-1945). - 연세 대학교 출판부, 1984년 09월 01일. 342쪽 (СоH IH-cy. Iсторія сучасної освіти в Кореї (1885-1945) / Yonsei University Press, 1984. 342 с.)

[15] 오성철. 식민지 초등 교육의 형성. - 교육과학사 2000년 02월 25일 출간. 468쪽 (О Сонг-чоль. Розвиток початкової освіти в колоніальний період / Історія педагогики, 2005. 468 с.)

[16] 현장 활용 워크숍 // 「2015 특수교육 교육과정 및교과용도서」현장 활용 워크숍, 2015. 276 페이지 (Польова майстерня передового досвіду / Семінар «Навчальний план спеціальної освіти та навчальні посібники у 2015 році», 2015. 276 c.) URL: http://www.kbe.go.kr/cmmn/ download.do?idx=1394959\&usg=AOvVaw1mhJ3FHXJKynwnwTYdv2Ag (дата звернення: 25.04.2019)

[17] 高橋漠吉. 朝鮮呚育史考. - 帝國地方行政學會朝鮮本部, 1927. 537 頁 (Такахаші Хамакічі. Історія освіти в Кореї / Кьонгсон: Штаб-квартира Чосон, 1927. 537 с.)

\section{References}

[1] An Su Mi (2005), Dialog kultur v istorii Korei, Moscow, 177 p. [in Russian]

[2] An Su Mi, Stanovleniie sistemy muzykalnogo obrazovaniia $v$ luzhnoi Koreie. Retrived from http://www.tsutmb.ru/nayk/nauchnyie_meropriyatiya/int_konf/mezhdunarodnyie/aktualnyie_ problemyi_soczialno_kulturnoj_deyatelnosti/konkurs_na_luchshee_osveshhenie_aktualnyix_ voprosov_soczialnoj_tematiki_v_rossii/stanovlenie_sistemyi_muzyikalnogo_obrazovaniya_v_yuzhnoj_koree [in Russian]

[3] Taishina, U.S. (2015). Muzykalnoie obrazovaniie v Koreie // Visshaia shkola, Institut after V.A. Bosikov. Muzyka dlia vseh, lakutsk. Iss. 4. pp. 20-23. [in Russian]

[4] Auh Myung-sook, \& Walker, R (2001). Korea / Musical Development and Learning: The International Perspective /I A.C. North, D.J. Hargreaves (eds). Chapt. 8. «Continuum». London-New York, pp. 102-120.

[5] Kean K.H. (2006) A Historical and Social Perspective of Korean Art Education / Georgia State University (USA), 113 p. Retrived from https://scholarworks.gsu.edu/cgi/ viewcontent.cgi?article= 1005\&context=art_design_theses

[6] Kim, Jeong-Ha (2013). Korean Primary School Music Education during Japanese Colonial Rule (1910-1945). 268 p. Retrived from https://research-repository.griffith.edu.au/handle/ 10072/367474

[7] Overview: The Development of Education. Retrived from http://english.moe.go.kr/ sub/info.do?m= 020101\&s=english

[8] "The School Curriculum of the Republic of Korea» Proclamation \#2008-3 of the Ministry of Education and Human Resources Development of the Republic of Korea. 2008. 53 p. URL: http://ictmsn.org/curriculum/the school curriculcum of the republic of Korea-2009.pdf

[9] "The School Curriculum of the Republic of Korea» Proclamation \#2008-160 of the Ministry of Education, Science and Technology of the Republic of Korea. 2008. 133 p. URL: http://gangwonepik.weebly.com/ uploads/1/ 3/8/5/ 13851570/ national_school_curriculum-english2008.pdf

[10] Kim, Hyeong-Mog, \& O, Seong Cheol. (2003). Chodeung-gyoyug-ui yeogsajeog tamsaeg: ilchodeung-gyoyug-ui yeogsajeog tamsaeg: iljegangjeomgi saseolchodeung gyoyuggigwan-ui yeoghal - hanmal 1920nyeondaeleul jungsim-eulo / Tolon. Balhaeng-gigwan: hangug chodeung gyoyughaghoe ganhaengmul: Hangug chodeung gyoyughaghoe hagsulbalpyononmunjib 2003gwon Oho balhaeng yeondo: 2003 peiji: pp. 145-170 (26 pages) (The study of primary school history: The role of the private primary school until 1920) [in Korean]

[11] Kim, Hye-Cheong. (1998). Iljeha eum-aggyoyugjeongchaeg yeongu: hag-winonmunsahang hag-winonmun (seogsa), Mogwon daehaggyo daehag-won: eum-aghaggwa. - Daejeon: Daigo Makino. 199 Chog (Study of the policy of musical education during the Japanese occupation) [in Korean]

[12] Pak, Chye-Hong. (2010). llje gangjemgi Changga e nattanan susin gyoguk - Joseonchongdogbupyeonchan「shi n'pen 'sho ka su」, 「futsu manabu ko sho ka sho „reul Jungsim-eulo. Ilbon gyoyug, 2010 53qweol. pp. 211-227 (Changga song 
education during the Japanese colonial power - collections by the Governor-General of Korea for songs focused on elementary school «New Collection of Songs», «Collection of Songs for the Junior School») [in Korean]

[13] Pak, Hye-Cheong. (2005). Seoyang-eum-ag-ui jeonlaewa suyong - 1880daereul gijeom-eulo han gaehwagi jungsim-eulo. Gug-aggwagyoyug 23gwonOho, 2005nyeon 12wol. peij: 231-266 (36 pages) (Appearance and perception of Western music - Orientation for the period of flowering since 1880) [in Korean]

[14] So, In-Su (1984). Hanguggeundaegyoyugsa (1885-1945). - Yeonse daehaggyo chulpanbu, 1984nyeon 09wol 01il. 342jjog (The history of modern education in Korea (1885-1945)) [in Korean]

[15] O, Seong-Jeol. (2005). Sigminji chodeung gyoyug-ui hyeongseong. - Gyoyuggwahagsa 2000nyeon 02wol 25il chulgan. 468jjog (Development of elementary education in the colonial period) [in Korean]

[16] Hyeonjang hwal-yong wokeusyob // 2015 teugsugyoyug gyoyuggwajeong michgyogwayongdoseo Hyeonjang hwal-yong wokeusyob, 2015. 276 peiji (Field Workshop on Excellence / Seminar «Curriculum for Special Education and Tutorials in 2015»). Retrived from http://www.kbe.go.kr/cmmn/download.do?idx=1394959\&usg= AOvVaw1mhJ3FHXJKynwnwTYdv2Ag [in Korean]

[17] Takahashi, Hamakichi. (1927). Josen' gyoyuk shiko. - Mikado kunichichigyo seimanabu Joseonbonbu, 1927. 537 peji (History of education in Korea) [in Japanese]

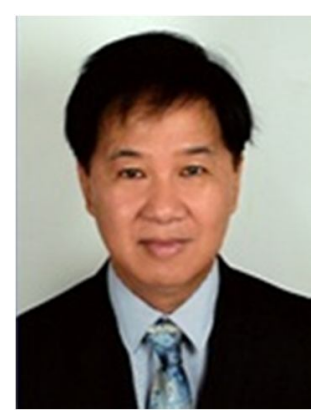

\section{Кім Олександр Олексійович.}

Аспірант,

Харківський національний педагогічний університет ім. Г.С. Сковороди,

к. 318, вул. Валентинівська, 318, корп. В., Харків, Україна, 61168.

Тел. (098) 037-23-56. E-mail: kim.sungdai@yahoo.com

\section{Kim Oleksandr Oleksiyovich,}

Post-graduate student,

H.S. Skovoroda Kharkiv National Pedagogical University,

room 318, Valentinivska st, 2 B, Kharkiv, Ukraine, 61168.

Тел. (098) 037-23-56. E-mail: kim.sungdai@yahoo.com

ORCID: https://orcid.org/0000-0002-9570-5243

\section{Citation (APA):}

Kim, O. (2019). Background of the formation of the modern system of musical and aesthetic education primary school students in the Republic of Korea. Engineering and Educational Technologies, 7 (2), 38-49. doi: https://doi.org/10.30929/2307-9770.2019.07.02.04

\section{Цитування (ДСТУ 8302:2015):}

Кім О. О. Передісторія формування сучасної системи музично-естетичного виховання молодших школярів в Республіці Корея / Інженерні та освітні технологіï. 2019. Т. 7. № 2. С. 38-49. doi: https://doi.org/10.30929/2307-9770.2019.07.02.04

Обсяг статmі: сторінок - 12 ; умовних друк. аркушів - 1,738. 